\title{
Urethral caruncle: Case report of a rare acute urinary retension
}

\section{cause}

\author{
Soner Çoban, $M D ;{ }^{*}$ Ismail Bıyık, $M D^{+}$ \\ *Department of Urology, Şevket Yılmaz Training and Research Hospital, Bursa, Turkey; †Department of Obstetrics and Gynecology, Karacabey State Hospital, Bursa, Turkey
}

Cite as: Can Urol Assoc J 2014;8(3-4):e270-2. http://dx.doi.org/10.5489/cuaj.1683 Published online April 14, 2014.

\section{Abstract}

A urethral caruncle is a benign vascular tumour usually originating from the rear lip of the external urethral mea and often observed in postmenopausal women. Urethral caruncle is not included within the list of bladder overdistension causes in women. We present urethral caruncle as a rare cause of acute urinary obstruction in a 41-year-old woman. The case was evaluated with physical examination and the bladder was evacuated with a 12-Fr urethral catheter. A pressure flow study was performed. The caruncle was excised under spinal anesthesia. There were no complications. The urethral catheter was withdrawn on the sixth day and she was discharged with local estrogen.

\section{Introduction}

Urethral caruncle is defined as a highly vascular polypoid lesion originating from the posterior wall of the external urethral mea of women and usually does not exceed $1 \mathrm{~cm}{ }^{1}$ It is the most common benign tumour of the female urethra after menopause. It consists of vascular connective tissue loosely surrounded with transitional and squamous epithelial cells. The most important risk factor in its etiology is hypoestrogenemia. Positive results have been reported with hormone replacement treatment. ${ }^{2}$

\section{Case report}

A 41-year-old female patient presented to the emergency department. She was unable to urinate and was referred to our clinic. The patient had overflow incontinence for about 2 years and had been urinating with the Credé's maneuver for 10 months. She had normal preoperative serum blood urea nitrogen (BUN) and creatinine levels. The physical examination revealed bladder overdistension. A $2 \times 1.5-\mathrm{cm}$ dark red mass that was soft on palpation, originating from the posterior lip of the external mea, was found while inserting a 14-Fr urethral catheter. Only a 12-Fr urethral catheter could be placed due to the meatal obstruction caused by the urethral caruncle. In total, $1500 \mathrm{cc}$ residual urine was removed. A pressure-flow study was performed to evaluate the acute urinary obstruction. We found a normo-sensitive, hypocompliant bladder with normal capacity and an unstable detrusor with higher than normal pressure. The patient could not urinate during the urination phase. The VLPP (valsalva leak point pressure) was negative (Fig. 1).

An 18-Fr cystoscopy was performed following the urethral dilatation under spinal anesthesia. The cystoscopy was normal and the symptoms were associated with the urethral caruncle. The caruncle was excised. No complication occurred during or after the operation. The urethral catheter was withdrawn on postoperative day 6 . She had normal postoperative serum BUN and creatinine levels. Local estrogen creams were also applied during the postoperative period. The patient started to urinate easily after the caruncle excision (Fig. 2)

\section{Discussion}

Although a urethral caruncle can be seen in the prepubertal period, it is often observed in the postmenopausal period as in our case. A urethral caruncle does not cause symptoms in patients; it is a cosmetic disorder, but can very rarely cause acute urinary retention. ${ }^{3}$

Although our patient could not urinate before the surgery, as seen in the pressure flow study, she did urinate easily after surgery during the uroflow investigation. A urethral caruncle can signal certain disorders and these should be looked for. These disorders include urethral thrombosis, pseudoneoplastic lesion, lymphoma, clitoral vein thrombosis, ureteral polyps, malignant melanoma, carcinoma, intestinal heterotype, angiomatous lesions and distal urethral stenosis. ${ }^{4-10}$ Although the initial medical treatment of urethral caruncle is topical 
Test notu

44 yaşında kadın hasta, yaklaşık 2 yıldır pollaküri ( 10 defa ), noktüri ( 5 defa ), kesik kesik işeme, rezidū idrar hissi şikayetleri mevcut. Anal tonus ve perine duyu muayenesi doğal. Hastanın rezidú idrarı kateter ile boşaltıldı, $350 \mathrm{cc}$ idrar geldi.

Normosensitif, Hipokomplian, 10cc/dk düşük dolum hızında sistometri aşamasında hastanın aşırı ağrı hissetmesi üzerine mesane 360 cc'ye kadar sıvı ile doldurulabildi. Dūşūk kapasiteli mesane. Normalden yŭksek basınçıı unstabil detrusör. Hasta işeme fazında idrarını yapamadı. VLPP: (-)

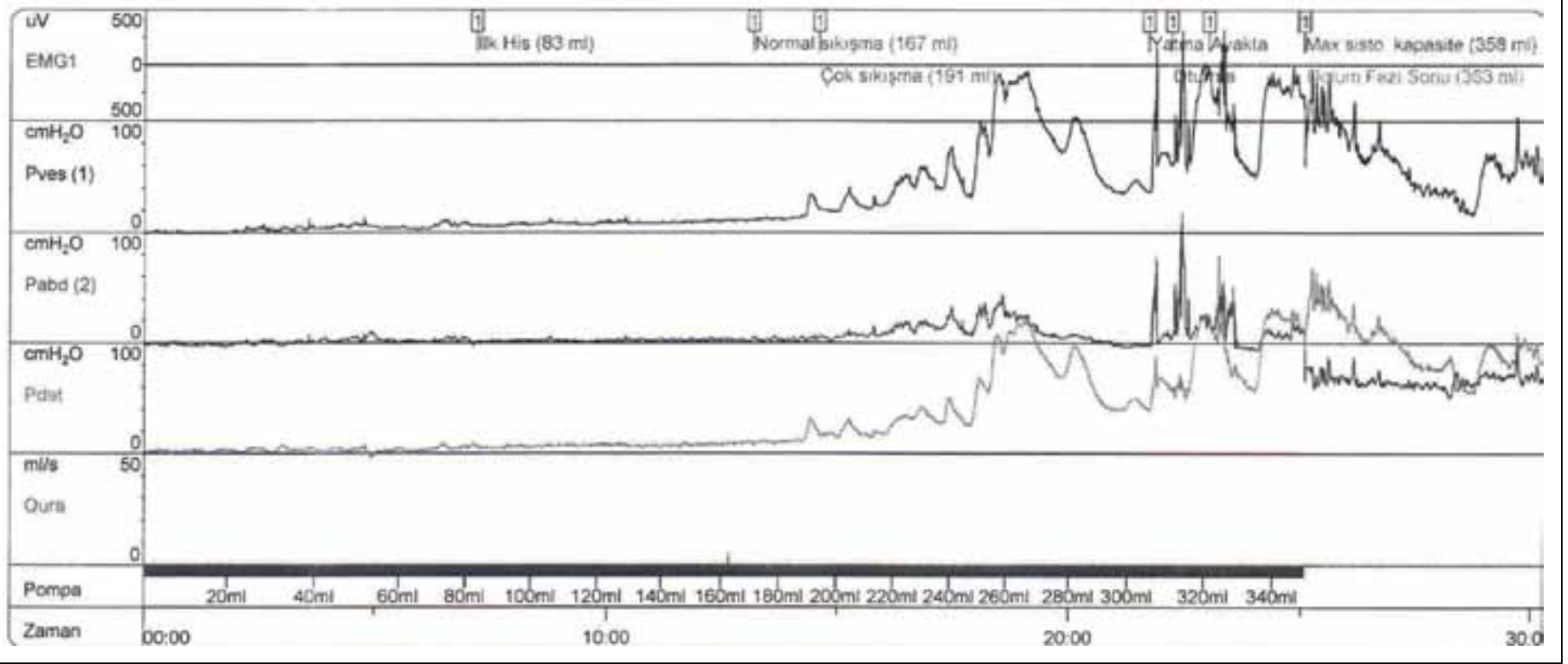

Fig. 1. Preoperative pressure flow study.

estrogen and anti-inflammatory treatment, we believe that the most effective form of treatment is total excision. Total excision is preferred because the mass can be large enough to make urinating difficult; there is also a small chance of malignancy. It can also be a sign of disease, such as carcinoma, so total excision is now favoured.

\section{Conclusion}

A urethral caruncle is rare among the causes of urinary retention. There is limited information on this subject. Pressure flow studies of the cases were not available in previous studies. Our case contributes to the literature in that we included a pressure flow study before and after the excision. A complete evaluation, including a pressure-flow study, should be performed in patient with a urethral caruncle, so that one can eliminate possible pathologies.

Competıng interests: Dr. Çoban and Dr. Biylk declare no competing financial or personal interests.
This paper has been peer-reviewed.

\section{References}

1. Hertig AT, Gore H, Sect X, FASC. 33. Tumors of the vulva, vagina and uterus, In: . Washington, DC; 1960:49.

2. Everett HS, Williams TJ. Urology in the female. In Campbell and Harrison Urology, 3rd edition, vol 3. Philadelphia, PA: Saunders Co; 1970:1957-70.

3. Tanagho EA, Brant WO, Lue TF. Disorders of the female urethra. In: Tanagho EA, McAnninch JW (eds.), Smith's General Urology. 17th ed. San Francisco, McGraw-Hill; 2008:638-44.

4. Urakami $S$, Igawa $M$, Shiina $H$, et al. Urethral caruncle with coexistence of intestinal heterotopia: A case report. Int Urol Nephrol 1997;29:341-4. http://dx.doi.org/10.1007/BF02550933

5. Becker LE. Urethral caruncle: A herald lesion for distal urethral stenosis? J Natt Med Assoc 1975;67:22830.

6. Young RH, Oliva E, Garcia JA. Urethral caruncle with atypical stromal cells lymphoma or sarcoma - a distinctive pseudoneoplastic lesion of females. A report of six cases. Am I Surg Pathol 1996;20:1190-5. http://dx.doi.org/10.1097/00000478-199610000-00003

7. Fernandez AM, De Castro BF, Cortes Al. Female urethral caruncle. A thrombosis of the dorsal venous complex? Actas Urol Esp 1998;22:443-5.

8. Lee WH, Tan KH, Lee YW. The aetiology of postmenopausal bleeding-a study of 163 consecutive cases in Singapore. Singapore Med J 1995;36:164-8.

9. Lopez JI, Angulo JC, Ibanez T. Primary malignant melanoma mimicking urethral caruncle. Case report. Scand J Urol Nephrol 1993;27:125-6. http://dx.doi.org/10.3109/00365599309180428 
Çoban and Bıyık

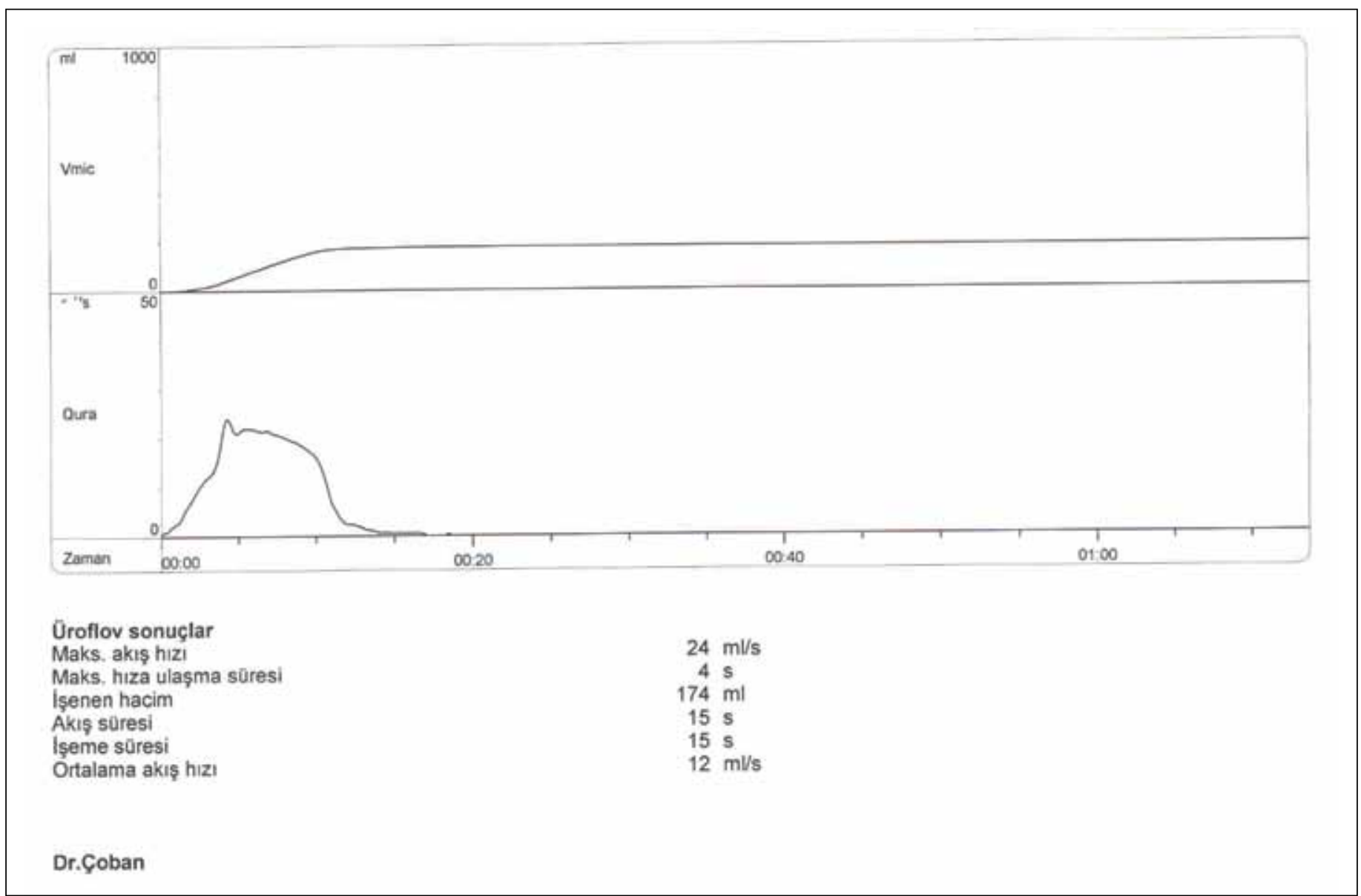

Fig. 2. Postoperative pressure flow study.

10. Kaneko G, Nishimoto K, Ogata K, et al. A case of intraepithelial squamous cell carcinoma arising from urethral caruncle. Can Urol Assoc J 201 1;5:E14-6. http://dx.doi.org/10.5489/cuaj.10027
Correspondence: Dr. Ismail Bıyik, Specialist in Obstetrics and Gynecology, Karacabey State Hospital, Tavsanli Street 56 Road No:4 16700 Karacabey/Bursa, Turkey; dribiyik@hotmail.com 